\title{
Experimental Study to Evaluate the Performance of Iraqi Passive House in Summer Season
}

\author{
Ghanim Kadhem Abdulsada ${ }^{1}$ and Tawfeeq Wasmi Mohammed Salih ${ }^{2}$ \\ 1. Mechanical Engineering Department, Al-Mustansiriyah University, Baghdad 15140, Iraq \\ 2. Materials Engineering Department, Al-Mustansiriyah University, Baghdad 15140, Iraq
}

Received: January 01, 2015 / Accepted: February 13, 2015 / Published: April 30, 2015.

\begin{abstract}
Iraq locates in hot arid region $\left(30^{\circ} \mathrm{N}-37^{\circ} \mathrm{N}\right)$, where the hot summer season is very long and the ambient temperature is about $50{ }^{\circ} \mathrm{C}$. Cooling of building needs $\mathrm{A} / \mathrm{C}$ (air-conditioning) system which consumes more than $60 \%$ of the total electricity supplied to residential building. So, there is really need to minimize the energy consumption by enhancement the performance of Iraqi buildings using passive house technique. This paper presents the thermal performance of a Passivhaus model built in Kirkuk ( $35^{\circ} \mathrm{N}$ ). The design depends on the using of suitable materials, sufficient insulation, well airtightness and underground air cooling. The experimental measurements take in consideration several parameters like ambient temperature, solar radiation, orientation of the building and duration. The results give good indication of the benefit of using this technique of passive cooling system in Iraqi residential buildings. The indoor temperature could be reduced to $30{ }^{\circ} \mathrm{C}$, while, the energy consumption for cooling could be saved up to $80 \%$.
\end{abstract}

Key words: Energy saving, passive system, building performance, thermal insulation, underground cooling system.

\section{Introduction}

The severe summer weather conditions in Iraq are a good example of arid climatic conditions with high level of solar radiation and large fluctuation of air temperature. In order to reduce the climatic effects upon buildings, it is important to adopt passive techniques like using insulating materials and air control system. The term Passivhaus (passive house) refers to the standard for energy efficiency in a building and reducing its ecological footprint. It results in ultra-low energy buildings that require little energy for space heating or cooling. Passive design is an attachment or supplement to architectural, structural, environmental and energy engineering design. Although it is mostly applied to new buildings, it has also been used for refurbishments [1]. Passive houses allow for energy savings of up to $90 \%$ compared with

Corresponding author: Tawfeeq Wasmi Mohammed Salih, lecturer, research field: energy conservation. E-mail: tawfeeq1978@yahoo.com. conventional buildings. The Passivhaus requirements have been formalized by the Passivhaus Institute in Darmstadt, Germany, where it should be satisfying air-conditioning demand not more than $15 \mathrm{kWh} / \mathrm{m}^{2} \cdot \mathrm{yr}$ (year) $\left(10 \mathrm{~W} / \mathrm{m}^{2}\right)$. This includes optimized insulation levels with minimal thermal bridges, very low air-leakage through the building, utilization of passive solar and internal gains and good indoor air quality maintained by an efficient mechanical ventilation system. Renewable energy sources are used to meet the resulting energy demand including that required for the provision of domestic hot water [2]. A theoretical study carried out by Almusaed et al. [3] shows that improving energy efficiency in performance of Iraqi building design can be satisfied by means of natural elements like using of insulation, shadow, air flow and rooms planning. The $U$-value of the optimized wall must be not exceeding $0.12 \mathrm{~W} /\left(\mathrm{m}^{2} \cdot \mathrm{K}\right)$. For an efficient roof, it needs to develop ways to get $U$-value of $0.082 \mathrm{~W} /\left(\mathrm{m}^{2} \cdot \mathrm{K}\right)$. A complete thermal bridge free construction is needed 
with linear thermal transmittance below $0.01 \mathrm{~W} /\left(\mathrm{m}^{2} \cdot \mathrm{K}\right)$. On a summer day, the temperature of a gravel roof can increase to $40{ }^{\circ} \mathrm{C}$, so using $15 \mathrm{~cm}$ of mineral wool is required. Also, shading of the roof can reduce air temperature as much as $5{ }^{\circ} \mathrm{C}$. A theoretical study carried out by Maerefat et al. [4] to improve passive cooling is presented using the solar chimney together with earth to air heat exchanger. The results show that this system with a proper design may provide a thermally comfortable indoor environment $\left(27-29{ }^{\circ} \mathrm{C}\right)$ for summer days in Iran and can be perfectly used to save electrical power. The chimney is covered by glass and faced toward south to capture maximum radiation. The underground heat exchanger cooling system is a plastic pipe of $25.0 \mathrm{~m}$ length, $0.5 \mathrm{~m}$ diameter buried $3.0 \mathrm{~m}$ below the soil surface. According to the model, the soil temperature is approximated to be $19{ }^{\circ} \mathrm{C}$ for a dry shaded soil surface condition and it is considered to be the heat sink temperature.

Roof surface is the most exposed to solar radiation and most of the solar gain absorbed by roofs are transmitted down to the inside space living because the roofs work as solar collectors. An experimental study carried out by Abdulsada [5] deals with the reducing of energy consumption in building using spray water to eliminate the effect of direct solar radiation in summer season. In that study, a system consisting of network piping, valves, spray nozzles and thermal sensors is stated to spray water upon the external roof surface. The results show that the energy transmission through the roof surface is reduced to only $4 \mathrm{~W} / \mathrm{m}^{2}$, while for the case of no spry water, the energy transmission rises up to $40 \mathrm{~W} / \mathrm{m}^{2}$.

In conclusion, the detailed design of the passive house must realize the following parameters:

(1) well insulated building envelope;

(2) high energy performing windows and doors;

(3) minimized heat loss through thermal bridging;

(4) significantly reduced structural air infiltration;

(5) optimal use of passive solar and internal heat gains.

\section{Experimental Work}

The aim of this study is to satisfy passive house criteria for Iraqi buildings and investigate the advantages and disadvantages of design during construction. The experimental study investigated the thermal behavior across two building models in Kirkuk $\left(35.5{ }^{\circ} \mathrm{N}, 44.4{ }^{\circ} \mathrm{E}\right)$ during the period August 01-October 04, 2013. These models are located in an open area where no shaded region. The first model was built in traditional way, while the second model was built according to Passivhaus standards. Both models have the dimensions $1.8 \mathrm{~m} \times 1.8 \mathrm{~m} \times 2 \mathrm{~m}$, as shown in Fig. 1. Each model has one window $0.8 \mathrm{~m} \times 0.5 \mathrm{~m}$ south orientation and one door $1.9 \mathrm{~m} \times 0.9 \mathrm{~m}$.

The traditional model is built using the conventional procedure. The wall of the traditional room is constructed from $20 \mathrm{~cm}$ common block, $2 \mathrm{~cm}$ external cement-plaster and $2 \mathrm{~cm}$ internal gypsum-plaster, while the roof is constructed from $15 \mathrm{~cm}$ steel-reinforced concrete with $2 \mathrm{~cm}$ internal gypsum-plaster.

The passive model should be built according to Passivhaus standards. Hence, the construction is done through several steps. The foundation built using standard $20 \mathrm{~cm}$ hollow block with the use of concrete mortar. The outer face of the foundation should be insulated by cork of $4 \mathrm{~cm}$ thickness to prevent heat transfer from the surrounding area to the interior. Walls are built up to $2 \mathrm{~m}$ high using the standard $10 \mathrm{~cm}$ hollow block. The reason for the use of smaller sized block is to reduce costs and take advantage of saving (whether material or work) for the purpose of covering the expenses of insulation materials later. Cementitious mortar is used for plastering the outer façade just to fill the spaces between the blocks and prevent cracks and insect growth. On the inner facade, $2 \mathrm{~cm}$ gypsum plaster is used. Roof is installed using standard sandwich panel of steel plate coated with $13 \mathrm{~cm}$ polyurethane foam. The initial insulation is done by $2 \mathrm{~cm}$ cork envelop the whole space and hold using a suitable adhesive. After that, the room is covered by air bubble 


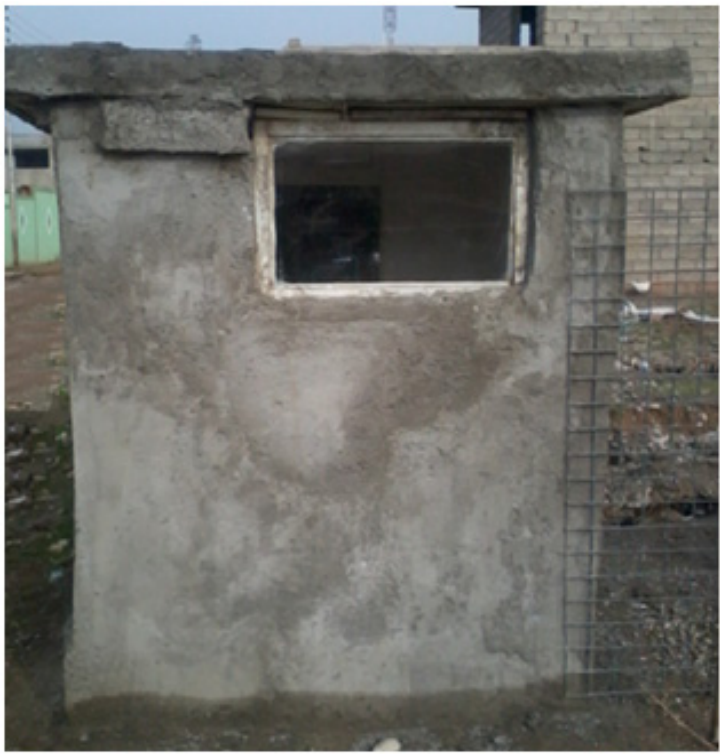

(a) Traditional model

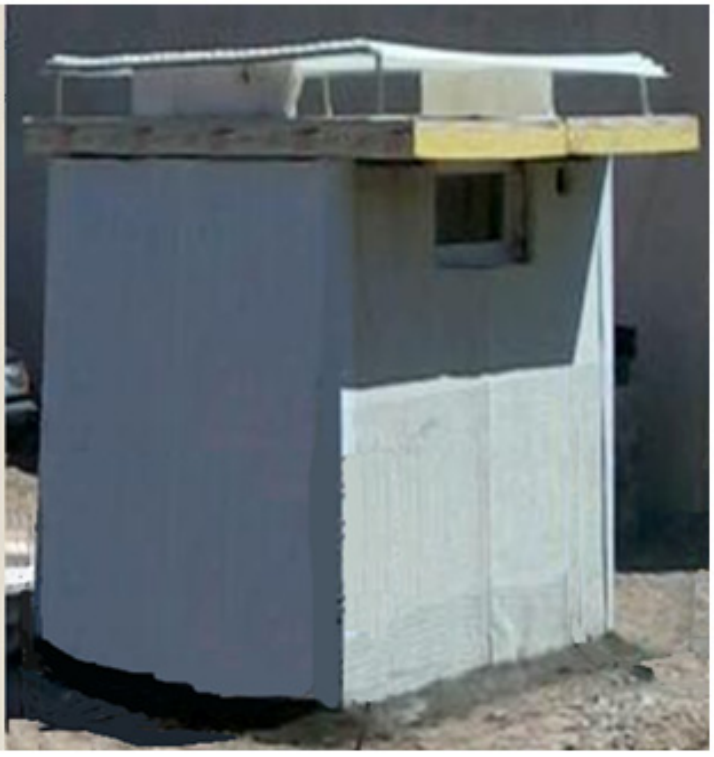

(b) Passive model

Fig. 1 Different models used in the study.

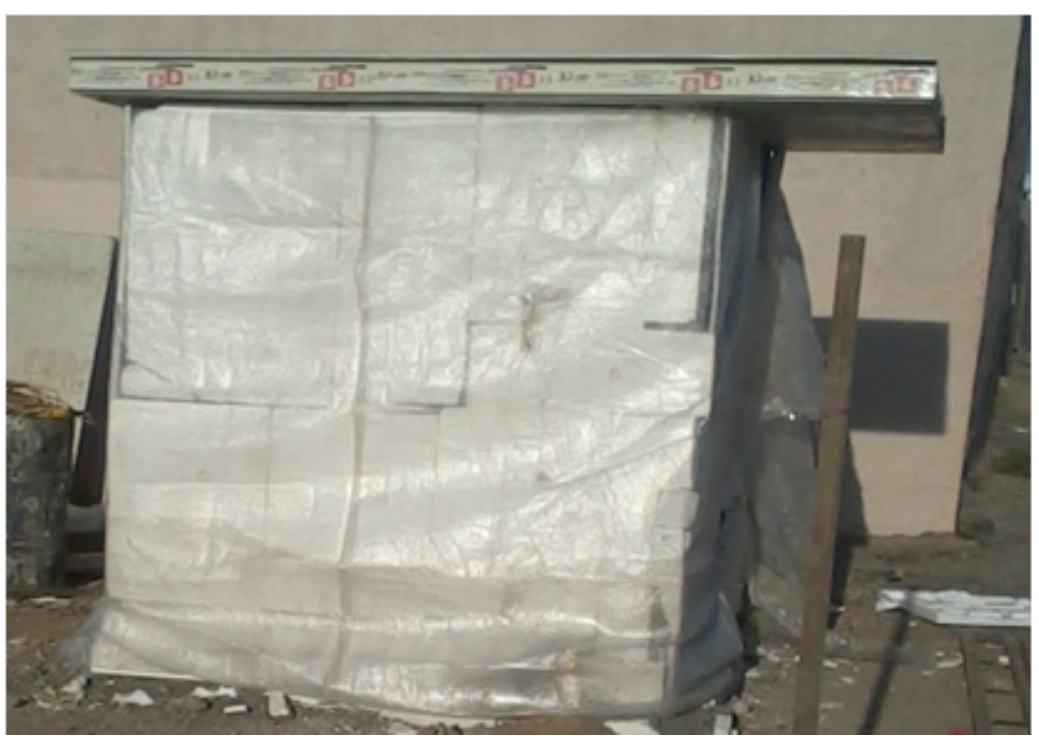

Fig. 2 Passive model is covered by air bubble wrap.

wrap of $4 \mathrm{~mm}$ thickness made up from polyethylene that is considered as thermal insulation and condensation barrier se well [6], as shown in Fig. 2. The next step is insulating of the room using sandwich panels of $10 \mathrm{~cm}$ polyurethane foam. The inner plate of the sandwich which faces the wall should be removed to prevent the transmission of heat through the plate sheet. The outer surface of the sandwich panel should be kept for the purpose of reflecting certain amount of radiation. Then the walls were wrapped with white sticker for the purpose of aesthetic. The $U$-value of the walls was $0.15 \mathrm{~W} /\left(\mathrm{m}^{2} \cdot \mathrm{K}\right)$ and the $U$-value for the roof was $0.19 \mathrm{~W} /\left(\mathrm{m}^{2} \cdot \mathrm{K}\right)$. Double gazing window of plastic frame is used. The dimensions of the window are $0.8 \mathrm{~m} \times 0.5 \mathrm{~m}$, and it is south orientation. It is noticed that the overall $U$-value of the window is 1.1 $\mathrm{W} /\left(\mathrm{m}^{2} \cdot \mathrm{K}\right)$. A closed-type window is used to ensure high airtightness. The glazing is assembled locally with the following specification: two glass layers of low-emittance, each layer of $4 \mathrm{~mm}$ thickness with 20 
mm evacuated space. Yellow coating is used to reduce absorption and increase reflection. Silica gel desiccant is used as wet absorption material and it sealed by aluminum bar. Door of UPVC frame and double sheeting is used. The dimensions of the door are $1.8 \mathrm{~m}$ $\times 0.9 \mathrm{~m}$, and it is north orientation. It is noticed that, the overall U-value of the door is $1.8 \mathrm{~W} /\left(\mathrm{m}^{2} \cdot \mathrm{K}\right)$. The essential thing related to passive house standard is killing the thermal bridging which is avoided around the wall, window and door using cork of 2-4 cm thickness. The airtightness is checked visibly using a lamp inside the room at night and seeing the places of leakage which should be processing by spray polyurethane. As known, roof is exposed to high intensity of solar radiation throughout the day, therefore a canopy of plastic (polyethylene) of $2 \mathrm{~m} \times 2 \mathrm{~m}$ is used to shade the roof and to supply continous air stream. The canopy is fixed above the roof with a distance of $30 \mathrm{~cm}$.

Controlled air enters to the passive model through a single slot connected to the underground cooling system and extracted from a diffuser at $2 \mathrm{~m}$ altitude which has northwest orientation where it is the most direction of wind blowing in Iraq, as shown in Fig. 3. Air flows through a 4 inch plasic tube down to the underground reservoir. The reservoir has a rectangular shape of $2 \mathrm{~m} \times 1 \mathrm{~m} \times 0.7 \mathrm{~m}$. Water level in the reservoir is about $30 \mathrm{~cm}$ and the rest is air. The reservoir is sealed by wood and suitable insulated materials. The mechanism of air cooling in the reservoir depends on the evaporating cooling which includes mass transfer of vapor at the water surface to the air which leads to increase the humidity content of it. This mechanism required involving in the details of mass transfer also the required time for cooling and the advantage of night flushing. The experiments showed that this system could reduce air temperature from $45{ }^{\circ} \mathrm{C}$ down to $34{ }^{\circ} \mathrm{C}$, making it acceptable before entering the room.

\section{Results and Discussion}

The study includes in-site measurements on selected buildings within two months (August and September) for both models (traditional and passive). It is advised

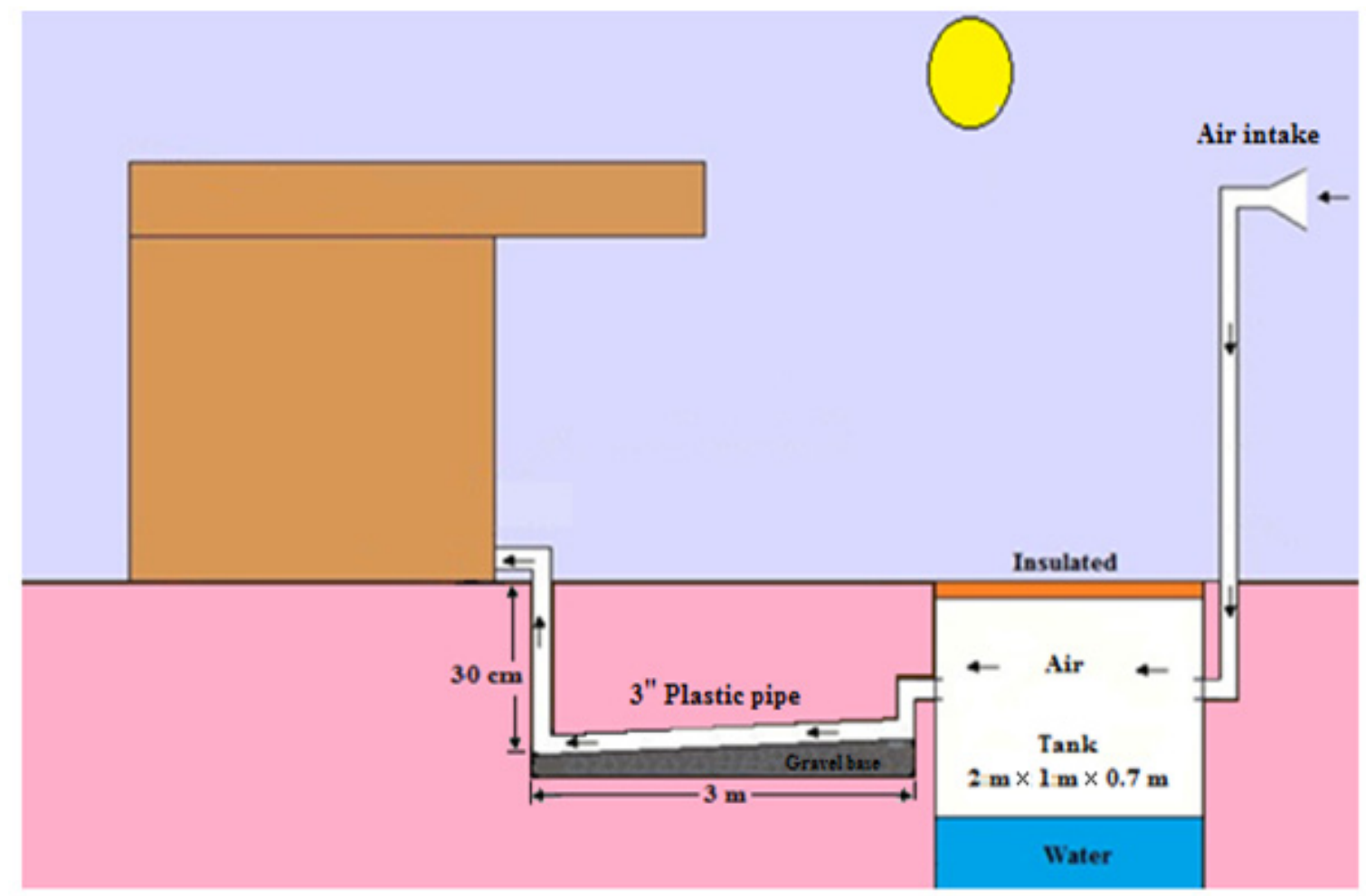

Fig. 3 Schematic diagram of underground air cooling system. 
to take more stable readings into consideration. Several instruments have been used in this project to measure the effective parameters in the building. Lutrun data logger system has been used to measure the outdoor, indoor, external surface and internal surface temperatures each $15 \mathrm{~min}$ throughout the day. The temperatures were measured at different places inside. The global solar radiation and relative humidity are measured as well.

Fig. 4 shows the variation of ambient temperature, indoor temperature and solar radiation within the period of experimental study for both traditional and passive models. In August, the outdoor temperatures are swinging daily from $30{ }^{\circ} \mathrm{C}$ (min.) to $48^{\circ} \mathrm{C}$ (max.) with solar radiation up to $950 \mathrm{~W} / \mathrm{m}^{2}$ for $13 \mathrm{~h}$. While for September, the outdoor temperatures are swinging daily from $24{ }^{\circ} \mathrm{C}$ (min.) to $40{ }^{\circ} \mathrm{C}$ (max.) with solar radiation up to $880 \mathrm{~W} / \mathrm{m}^{2}$ for $12.5 \mathrm{~h}$. The results show decreasing in the indoor temperature for the case of passive model compared with that of traditional one. In August, the average indoor temperature of passive model was $\left(32^{\circ} \mathrm{C}\right)$ with maximum value of $\left(34^{\circ} \mathrm{C}\right)$, while it was $\left(40^{\circ} \mathrm{C}\right)$ with maximum value of $\left(43^{\circ} \mathrm{C}\right)$ for traditional model. However, it is clearly that there is a flactuationg in max-min temperatures about $\left(3^{\circ} \mathrm{C}\right)$ in indoor temperature for passive model compared to that of traditional which is fluctuated about $\left(7^{\circ} \mathrm{C}\right)$.

Three ventilation cases were examined within this study which are free ventilation daytime and night, free ventilation daytime with night flushing and finally forced ventilation daytime and night. In order to study these cases in good manner, they are classified into several runs, as shown in Table 1.

In free ventilation, the air is supplied to the passive room naturally due to temperature difference and in presence of underground cooling system. The results show that, ambient air can be cooled down in the heat exchanger to supply air of $34{ }^{\circ} \mathrm{C}$ temperature to the building. Night flushing ventilation could be used to deliver direct air when the ambient temperature becomes cold (lower than $30{ }^{\circ} \mathrm{C}$ ). While in forced ventilation, the warm air from outside is withdrawn into the cooling system using a suction fan. However, it should be take care to make balance between the amount of cold air stored and the air flow rate supplied to the building because the rapid veocity would be unusefull specially with the using of forced ventilation, and in this case, it should be avoid suction very hot air during daytime which causes of rising the indoor temperature.

In Iraq, due to low ambient humidity $(20 \%-40 \%)$ in summer, there is no need for dehumidification. However, in the present work, the indoor relative humidity still cofortable, as shown in Fig. 5.

Fig. 6 shows the needing of canopy to reduce the influence of dirct solar radiation up on the roof. This system provides shading and air stream which helps to remove the accumulated heat through the roof. It is found that, the average reduction in the temperature of external surface of roof was $10{ }^{\circ} \mathrm{C}$ and the average

Table 1 Plan of work.

\begin{tabular}{|c|c|c|c|}
\hline Case & Duration & Specification of traditional model & Specification of passive model \\
\hline 1 & Aug. 01-Aug. 11 & $\begin{array}{l}\text { No insulation, insufficient window and door, no } \\
\text { overhang, no canopy, no ventilation system }\end{array}$ & $\begin{array}{l}\text { Insulation, sufficient window and door, overhang, no } \\
\text { canopy, free ventilation system }\end{array}$ \\
\hline 2 & Aug. 12-Aug. 27 & As it is & $\begin{array}{l}\text { Insulation, sufficient window and door, overhang, } \\
\text { canopy, free ventilation, system }\end{array}$ \\
\hline 3 & Aug. 28-Aug. 29 & As it is & $\begin{array}{l}\text { Insulation, sufficient window and door, overhang, } \\
\text { canopy, free ventilation system with night flushing }\end{array}$ \\
\hline 4 & Aug. 30-Sep. 04 & As it is & $\begin{array}{l}\text { Insulation, sufficient window and door, overhang, } \\
\text { canopy, free ventilation system }\end{array}$ \\
\hline 5 & Sep. 05-Sep. 07 & As it is & $\begin{array}{l}\text { Insulation, sufficient window and door, overhang, } \\
\text { canopy, forced ventilation system }\end{array}$ \\
\hline 6 & Sep. 08-Oct. 04 & As it is & $\begin{array}{l}\text { Insulation, sufficient window and door, overhang, } \\
\text { canopy, free ventilation system }\end{array}$ \\
\hline
\end{tabular}




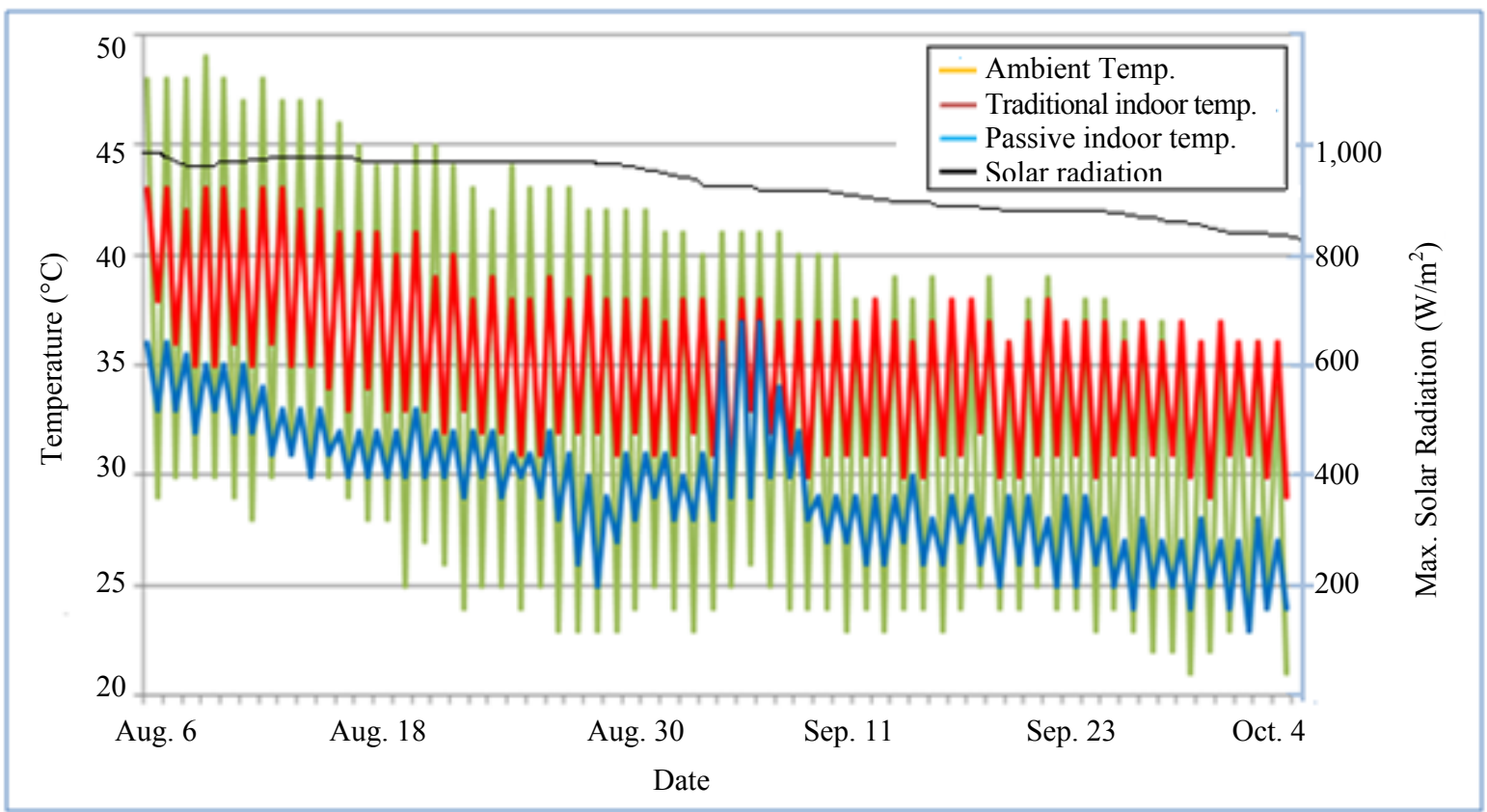

Fig. 4 Variation of indoor temperature during (Aug. 06-Oct. 04).

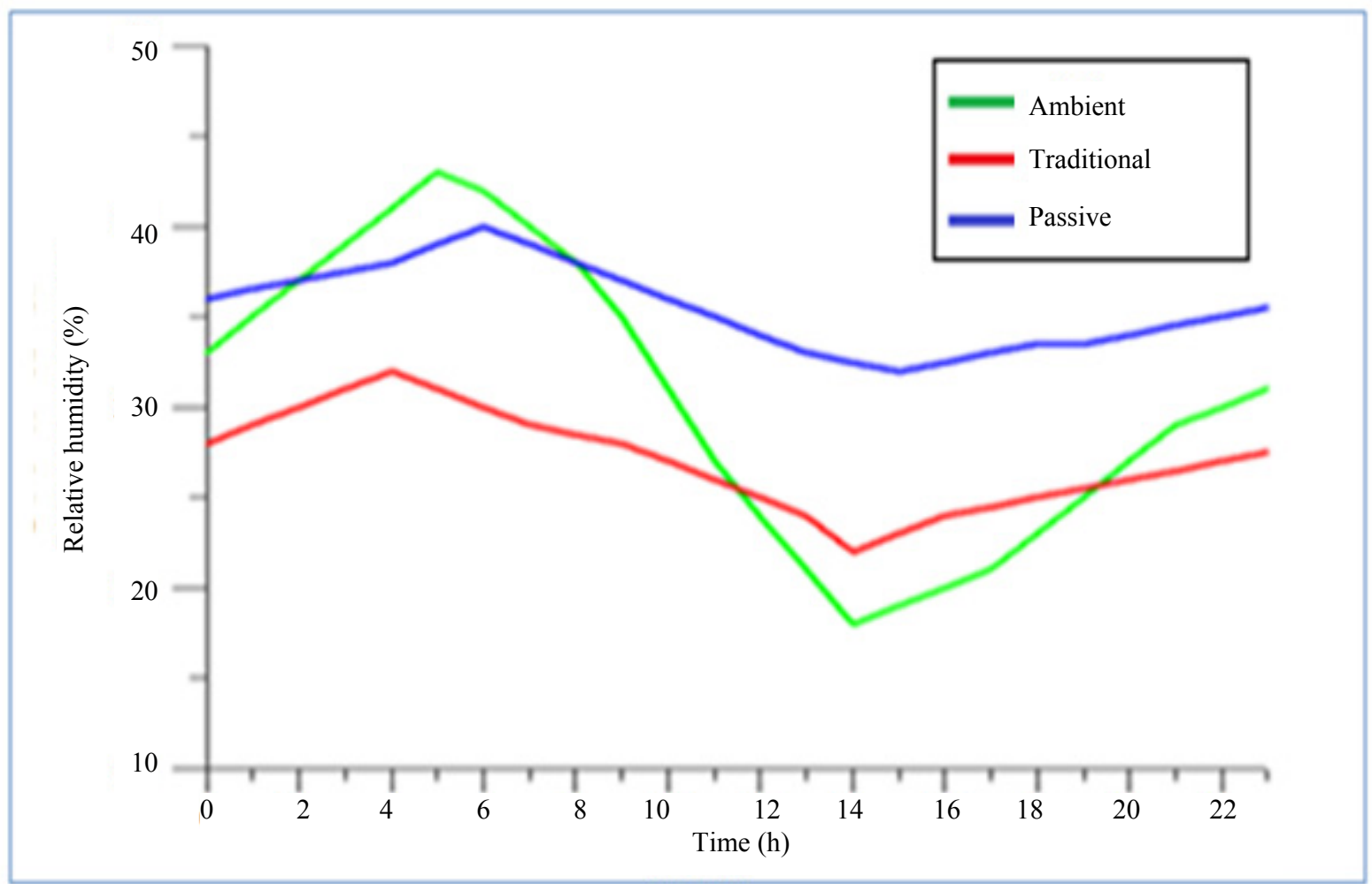

Fig. 5 Comparison for indoor air humidity on Aug. 15, 2013.

reduction in the temerature of internal surface of roof was $3{ }^{\circ} \mathrm{C}$ with average decreasing in indoor temperature by $2{ }^{\circ} \mathrm{C}$.

Based on the results obtained by the experimental work, the calculation showed that the annual energy consumption for a passive house is about $68 \mathrm{kWh} / \mathrm{m}^{2} \cdot \mathrm{yr}$, while for a traditional house is about $350 \mathrm{kWh} / \mathrm{m}^{2} \cdot \mathrm{yr}$. Then, the annual energy saving would be about $80 \%$. 


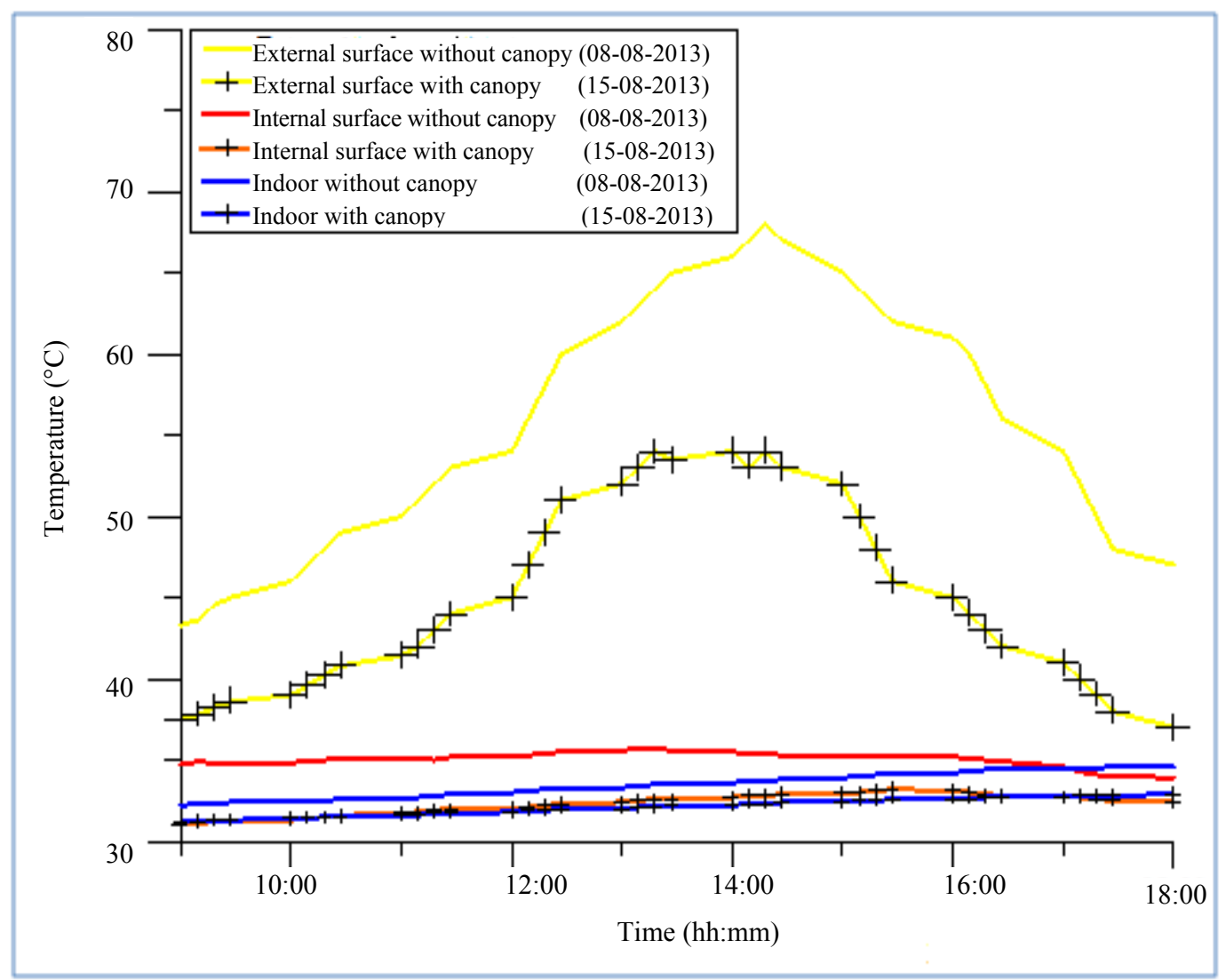

Fig. 6 Comparison for the effect of roof canopy.

\section{Conclusions}

This method gives good indication for using the passive house criteria in hot arid rejoins like Iraq where high level of solar radiation and large fluctuation of air temperature. In order to reduce the climatic effects upon buildings, it is important to adopt passive house techniques including best insulating materials, avoiding thermal bridges and air control system. Many conclusions can be drawn from this study which can be summarized as follows. The indoor temperature could be reduced to $31{ }^{\circ} \mathrm{C}$ instead of $42{ }^{\circ} \mathrm{C}$ for conventional house, and the energy consumption could be saved up to $80 \%$.

\section{References}

[1] Passivhaus Institute. 2006. "Definition of Passive House." Passivhaus Institute. Accessed May 20, 2013. http://www.passivhaustagung.de.

[2] Passive House Institute. 2010. "What is a Passive House?" Passive House Institute. Accessed May 10, 2013. http://www.passipedia.org.

[3] Almusaed, A., Khalil, A., and Almusaed, A. 2008. "Towards a Zero Energy House Strategy Fitting for South Iraq Climate." Presented at the PLEA 2008-25th Conference on Passive and Low Energy Architecture, Dublin, Irland.

[4] Maerefat, M., and Haghighi, A. 2010. "Passive Cooling of Buildings by Using Integrated Earth to Air Heat Exchanger and Solar Chimney." Renewable Energy Journal 35 (10): 2316-24.

[5] Abdulsada, G. K. 2013. "Techniques to Reduce the Energy Consumption in Building in Hot Arid Rejoin (Iraq)." Journal of Energy and Power Engineering 7 (June): 1052-7.

[6] Aerolam. 2013. "Bubble Wrap Insulation." Aerolam Insulation Private Limited Company. Accessed December 10, 2013. http://www.aerolaminsulations.com. 